POLSKA A ǨADEMIA NA UKK - Z̃AKEAD BADANIA SSAKOW

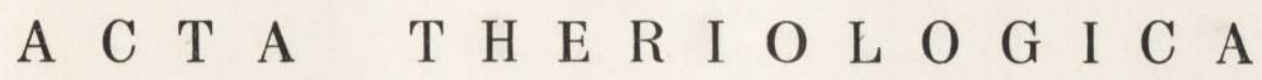

VOL. VII, 6.

BIAŁOWIEŻA

15.IX.1963

Ewa P E R K O W S K A 1

\title{
Investigations in Blood Tissue of Some Micromammalia
}

\section{Badania nad thanką krwiotwórczą u niektórych Micromammalia}

\author{
[With 6 figs. \& 2 tables]
}

I. Introduction

II. Material and methods .

III. Experimental

1. Morphology . . . . . . . , . . . . . . 70

2. Formation of the specific erythropoesis in the life cycle of Sorex araneus and related species. . . . . . . . . 73

IV. Discussion

V. Summary .

References

Streszczenie

\section{INTRODUCTION}

The morphology of blood tissue in wild animals is rather scarcelly investigated and comparatively little known. Therefore it was of interest to join in investigations of the biology of Micromammalia carried out in Białowieża, and work on the morphology of the blood tissue in some Insectivora, the Common shrew in particular, and in some rodents. The material came from the Białowieża National Park. I shall not describe the methods of collecting the animals, nor shall I give an analysis of the environmental conditions in which the animals were found. References concerning these problems can be found in works by Dehnel $(1949 ; 1950)$ and Borowski \& Dehnel (1952). Data concerning the biology of the Common shrew can be found in publications mentioned above and in a short monograph by $\mathrm{Crow} \mathrm{c} \mathrm{r} \mathrm{of} \mathrm{t} \mathrm{(1957).}$

I should like to thank here Mrs. Zofia $\mathrm{K}$ a r un os for her industrious and patient preparations of blood and tissue smears.

1) Present address: Zoological Institute, Dept. of Cytology, Warsaw University, Warsaw, Krakowskie Przedmieście 26/28. 


\section{MATERIAL AND METHODS}

The material consisted of bone-marrow, spleen, liver and blood smears prepared from 319 specimens of Sorex araneus Linn a e s, 1758, collected within one year. These fall into two groups: 153 young adult animals, aged from few weeks up to 9 months, leading already an independent life, but yet sexually undeveloped; and 166 old adults, i.e. animals mature and sexually active. This material was sufficient for estimations of the age-variability and seasonal variability as reflected in the blood tissue inside the species. Other Insectivora investigated in this respect were: 39 Sorex minutus L in na e u s, 1766, 10 Sorex caecutiens Laxman n, 1788, 27 Neomys fodiens (P e n n a n t, 1771), 5 Neomys anomalus milleri M o t t a z, 1907, 4 Talpa europaea $\mathrm{L}$ in $\mathrm{n}$ a e u s, 1758.

Among rodents following animals were investigated: 120 Clethrionomys glareolus ( $\mathrm{S} \mathrm{chreber}, 1780$ ), 17 Apodemus flavicollis (M elchior, 1834), 10 Sicista betulina (P a 11 a s, 1779), 2 Dryomys nitedula (P a 11 a s, 1778).

For morphological inspections, the air dried smears were fixed in ethyl alcohol and stained with Giemsa-Romanoffsky method. Benzidine method was applied for the estimation of haemoglobin in the erythrocytes and erythroblasts ( $\mathrm{M}$ a x i mov, 1949). Weltman's coagulation test for protein estimation in blood was used in six cases in which as controls served blood samples from six white mice (M a x i mov, 1949).

Nucleic acids were detected by the Unna-Pappenheim method. Enzymatic control was carried out by means of saliva reagent according to B r a c het (1948).

\section{EXPERIMENTAL}

\section{Morphology}

The general morphology of the blood tissue in Soricidae did not differ from that known in laboratory animals and rodents investigated in this work. The data concerning percentages of neutrophiles, histiocytes, lymphocytes and other cells did not differ from those known for the same kind of cells in laboratory animals and in wild rodents (literature and own investigations). On the other hand the erythropoesis seemed to be highiy specific. It showed a strong renewal of the erythropoetic tissue, which lasted throughout the whole life of the animals and was specially marked in very young specimens. The mean percentage values were as follows:

$\begin{array}{ll}\text { pronormoblasts } & 10 \% \\ \text { basochromatophiles } & 10 \% \\ \text { polychromatophiles } & 27 \% \\ \text { orthochromatophiles } & 53 \%\end{array}$

In older animals the number of polychromatophiles still rose, because a great number of them changed into characteristic cells resembling plasmacells. In these animals as well as in the old adults the percentage of such cells oscilated between 6 do $25 \%$ of all erythroblasts. At the same time the erythropoesis remained very high as evidenced by a very high number of pronormoblasts and basochromatophiles. In the old adults the 
number of neutrophiles seemed rather low not exceding $30 \%$ of all bløod cells.

All erythroblasts showed a greater volume of cytoplasm in relation to the nucleus than it is usual in the blood cells of other animals. The cytoplasm in pronormoblasts and basochromatophiles produced very often pseudopodia and other protrusions which separated from the main body of the cell, forming cytoplasmic drops devoid of nuclei and lied freely among other cells (Fig. 1, Plate IX).

Late basochromatophiles and early polychromatophiles underwent specific morphological changes in older young animals and in all old adults which lead to plasmacell-like forms. Similarly as in the plasmacells these changed cells had an abundance of cytoplasm. It was strongly basophilic and showed the unstainable spot, the Golgi or chondriom region which is rather characteristic for plasmacells. The nucleus was also characteristically shifted to the perifery of the cells (Fig. 2, 3, Plate IX).

These specific changes in erythropoesis occured in all Soricidae investigated, but with different intensity in different species. Therefore attention was drown to the possibility of occurrence of similar changes in the morphology of the erythroblasts in other animals, in this case in rodents, which inhabit similar ecological regions, and are caught in the same areas with the Soricidae. Indeed, it became possible to detect in rodents some transitory cells, namely some polychromatophiles which showed unusually abundant cytoplasm, excentric nucleus etc. making them slightly similar to plasmacells. These cells were found especially often in Sicista betulina (Fig. 4).

As the morphology of the erythropoetic tissue in Sorex resembled so much plasmacytosis, it was necessary to see if it provoked similar physiological responses of the whole body of the animal, as plasmacytosis does; and therefore the level of proteins in blood and blood coagulation were checked. Plasmacytosis in man and laboratory animals is accompagned by a heightened level of proteins in blood, as well as changed blood coagulation. Six old adult $S$. araneus which showed a very high percentage of changed erythroblasts were investigated in this respect. Six white mice whose bone-marrow was devoid of such cells served as controls. Blood coagulation was estimated at the same time. In protein coagulation test, the Weltman's band did not show any lengthening nor shortening for $S$. araneus in comparison to that for mice: coagulation appeared in the 6 th and 7th tube in both cases. The time of blood coagulation was also identical for both groups of animals and lasted about 3.5 minuts. Thus the presence of changed erythroblasts in the Soricidae have no effect neither on the protein level, nor the coagulation of the circulation blood, contrary to such effects in true plasmacytosis, 
Because of the very high rate of erythropoesis the haemoglobin content of the cells was histologically investigated by the benzidine method. Haemoglobin appeared in the erythroblasts of $S$. araneus very late, barely in late orthochromatophiles. In other animals the haemoglobin usually appears already in late basochromatophiles, but in our case these cells together with the polychromatophiles, the plasmacell-like cells, the orthochromatophiles and the free cytoplasmic drops did not show any staining with benzidine. The same is true for the transitory cells observed in rodents. This late appearence of haemoglobin is observed also in other representatives of the Insectivora - the Neomys Ka u p., 1829. It is interesting that in Neomys anomalus the conditions are intermediary between that of $S$. araneus and Neomys fodiens. Table 1 shows the comparative values for haemoglobin as estimated by the staining intensity of erythroblasts. The staining intensity of the orthochromatophiles of Clethrionomys glareolus being denoted as ++++ .

Table 1.

Staining of haemoglobin in erythroblasts in Soricidae and in Clethrionomys glareo!us with maximum staining denoted as ++++ .

\begin{tabular}{|c|c|c|c|c|}
\hline \multirow[t]{2}{*}{ Species } & \multicolumn{2}{|c|}{$\begin{array}{l}\text { Staining of the } \\
\text { polychromatophiles }\end{array}$} & \multicolumn{2}{|c|}{$\begin{array}{l}\text { Staining of the } \\
\text { orthochromatophiles }\end{array}$} \\
\hline & bone-marrow & spleen & bone-marrow & spleen \\
\hline S. araneus & +--- & +--- & +++- & $++t-$ \\
\hline S. minutus & +--- & +--- & +++- & +++- \\
\hline N. anomalus & ++-- & ++-- & ++-- & ++-- \\
\hline N. fodiens & $++t-$ & $+t+-$ & $+t+t$ & $++t+$ \\
\hline C. glareolus & +++- & +++- & ++++ & $+t+t$ \\
\hline
\end{tabular}

The presence of ribonucleic acid which should be responsible for the strong basophilia of the cytoplasm was checked by the Unna-Pappenheim method. Indeed, the pyronine, which is specific for this acid, stained not only all the erythroblasts but even slightly the freshly matured erythrocytes. Enzymatic control digestion with saliva according to $\mathrm{Brachet}$, stopped staining with pyronine. The pyronine staining was very strong especially in the youngest erythroblasts i.e. in the pronormoblasts, and basochromatophiles. It was still very strong in the polychromatophiles and the free cytoplasmic drops and quite perceptive in the orthochromatophiles and even erythrocytes. In the rodents the affinity to pyronine stopped at the stage of early orthochromatophile, On the contrary, the 
intermediary cells found some times in the rodents stained with pyronine well. The changed erythroblasts of the Soricidae with their large amount of cytoplasm and therefore large amount of ribonucleic acid seem to play the role of storage cells for this acid.

\section{Formation of the specific erythropoesis in the life cycle of $S$. araneus and related species}

As it was shown above, a specific erythropoesis was detected in some species of Sorex and related Insectivora. This changed erythropoesis is characterized by making the whole blood tissue look like a case of plasmocytosis. But physiological investigations have shown also, that the changes did not produce effects usually accompanying true plasmacytosis. This specific erythropoesis occured in all shrews investigated, young aduits and old adults, except in very young specimens.

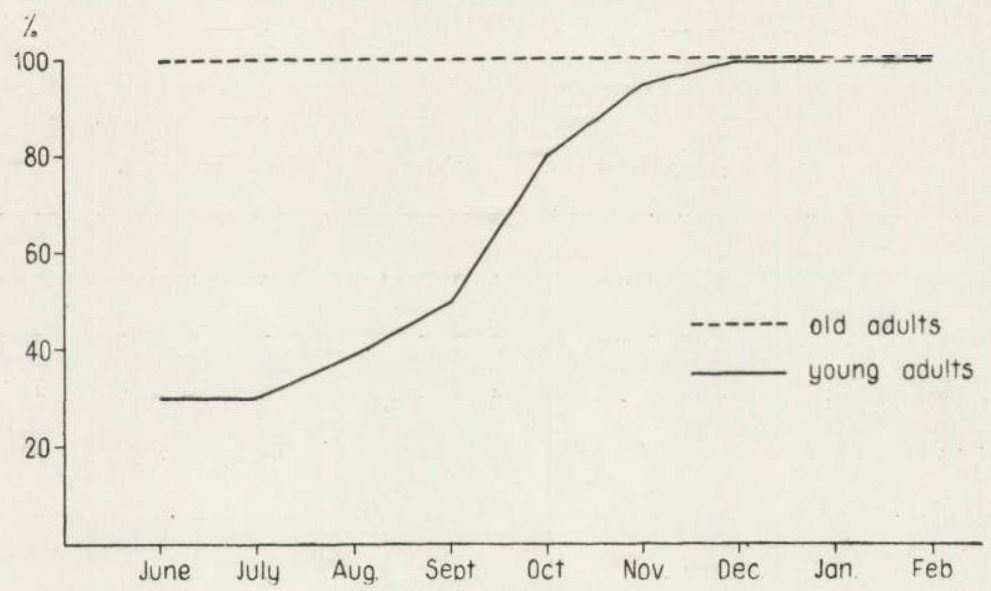

Fig. 5. Rate in development of erythropoetic changes in the life cycle of Sorex araneus.

In very young specimens of $S$. araneus during the first few weeks of independent life, the plasmacell-like cells did not occur at all. But already in June, that is in time when the animals have lead about 2-4 weeks of independent life, one found individuals with a marked number of changed cells in their blood tissue. From this moment on the number of such cells grows quickly and attains the values characteristic for old adults in animals aged $5-6$ weeks of independent life.

As the Fig. 5 shows, in the summer-autumn period the percentage of animals with changed erythroblasts increased steadilly. At the beginning of November $100 \%$ of animals possessed already changed cells.

The characteristic shape of the curve is due to the fact that the shrew brings forth its youngs from May till September and in the material 
collected during this time many very young specimens were caught in which the erythropoetic changes did not yet occur. As the end of multiplication of the shrew comes in September, the maximal length of time during which the animal develops erythropoetical changes should be about 6 weeks. The dashed line represents the percentage of old adults with erythropoetic changes. The solid line shows only the percentage of young animals which developed the above mentioned changes. Control investigations of shrews from other parts of Poland have shown the same changes as those observed in Białowieża. Although not so many specimens of Sorex minutus L i n n e u s, 1776 and Sorex caecutiens L a x m a n, 1778 were investigated as those of $S$. araneus, the occurrence and deve-

Table 2.

Rate of erythroblastic changes, with maximal rate of changes denoted as $++4++$ in Soricidae and in Talpa europaea

\begin{tabular}{|c|c|c|c|c|}
\hline \multirow{2}{*}{ Species } & \multicolumn{2}{|c|}{ Young adults } & \multicolumn{2}{|c|}{ Old adults } \\
\hline & bone-marrow & spleen & bone-marrow & spleen \\
\hline S. araneus & +++- & +++- & ++++ & $++t+$ \\
\hline S. minutus & +++- & +++- & $++t+t$ & $++t+$ \\
\hline S. caecutiens & +++- & +++- & $+t+t$ & $+t+t$ \\
\hline N. anomalus & & & +++- & $+t+-$ \\
\hline N. fodiens & $--\cdots$ & $+--\cdots$ & +--- & ++-- \\
\hline T. europaea & $-\cdots-\cdots$ & $-\cdots$ & ---- & +--- \\
\hline
\end{tabular}

lopment of erythropoetic changes was found to run along the sam? patterns as in Sorgx araneus.

It is of interes to compare the occurrence and development of the changed erythropoesis in yet another Insectivora, animals related to the Common shrew. There were no catch of very young specimens of $N$. ancmalus milleri, but in old adults the changed erythropoesis appeared in the blood tissue, both in bone marrow and in the spleen although the number of changed cells was evidently smaller than in the Common shrew. In still smaller number they appeared in the next species investigatec, Neomys fodiens. In the younger animals of this species, the changed cels did not occur in the bone marrow and only sporadically in the spleen. In the old adults only sporadically in the bone marrow and few in the spleen, 
In the mole, Talpa europaea, (two old adults and two youngs were investigated) some changed erythroblasts were found only in the spleen of the old aduits. In table 2 the number of changed cells in S. araneus was denoted arbitrarilly as ++++ and the conditions in related Soricidae and in the mole represented accordingly.

In all rodents which were caught at the same time and in the same conditions as the Soricidae and the age of which covered the same life span from very young to old adults, no changed erythroblasts were ever found. But occasionally in the spleen there could be observed few polychromatophiles with especially extended cytoplasm and slightly shifted nucleus. These cells have been considered as intermediate between the normal erythroblasts and the observed changed cells of the Soricidae.

\section{DISCUSSION}

It looks as if the Common shrew as well as other species of the family Soricidae, is an animal whose general biology differs markedly from what is usually found for other mammals. First of all, it shows a high metabolism. Known investigations by Tupi k ova (1949) have shown that the adult shrew after 12 hours and the young one after 8 hours of fast invariably dies. The shrew needs very great quantities of food (mostly insects); therefore atmospheric conditions and the day-night cycle leads to periods of prosperity and periods of difficulties providing a stress which in turn creats some physiological unrest of the organism.

Investigations by $\mathrm{Dehnel}(1949)$ and his colaborators have shown that from the second half of July, in the shrews (in the young ones as well as in the old adults) begin to occur specific changes in the skeletal bones. They start in the region of the sagital suture of skull (and perhaps in other regions of the skeleton also) and consist in the resorption of the bone tissue (P u c e k, 1955). This resorption explains the seasonal changes of the skull which appears as a diminution of it's height, earlier observed by Deh nel (1949). The process starts in the second half of summer and ends at the end of winter (February). From the middle of March revers processes begin to operate and the skull begins to heighten. Thus, in May the old adults have already a tall skull, although never as tall one as the young animals. Histological investigations by P u ce k (1957) have shown that in the areas where resorption operated, appeared osteoblasts which rebuilt the missing bone material. In July a second regression of the height of the skull occurs in the old adults and lasts till the natural death of the animals. This happens in autumn or winter of the second calendar year of their life. Seasonal changes in the skull (height per bullae, brain-case capacity) are a secondary phenomenon dependent on the seasonal 
variations in the brain-weight ( $\mathrm{P} \mathrm{u} \mathrm{c} \mathrm{e} \mathrm{k,} \mathrm{1955;} \mathrm{C} \mathrm{a} \mathrm{b} \mathrm{oń,} \mathrm{1956;} \mathrm{B} \mathrm{i} \mathrm{e} \mathrm{la} \mathrm{k}$ \& P u c e k, 1960). Similar changes happen in other organs and these occur with the same seasonal regularity and in correlation with those observed in the skull. A characteristic picture of these changes is represented in Fig. 6. It shows that practically during the whole life cycle, the organism of the shrew remains unbalenced.

A somewhat tangible indication of such an unstability is the changeability of the thymus. It undergoes an involution already in autumm in the first calendar year of the life of the shrew. The rate of changes which the thymus undergoes is so great ( $\mathrm{B} \mathrm{a} \mathrm{z} \mathrm{a} \mathrm{n,1952)} \mathrm{that} \mathrm{they} \mathrm{can} \mathrm{be} \mathrm{explained}$ by nothing else except by transitory conditional changes.

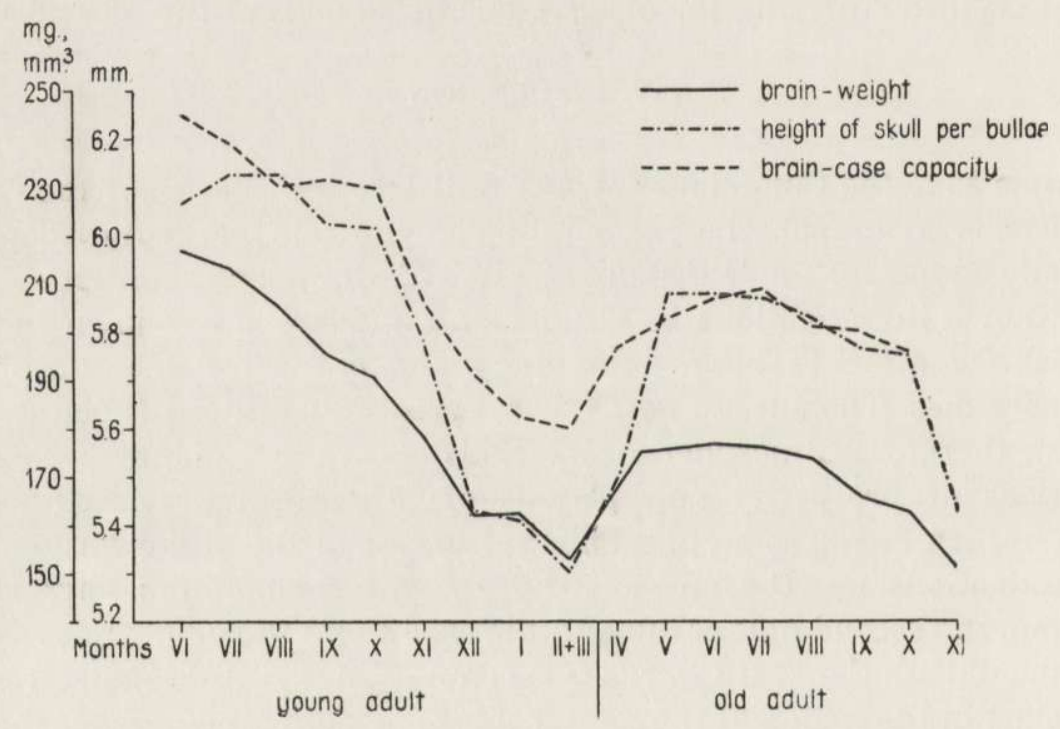

Fig. 6. Seasonal changes in the brain-weight, height of skull and brain-case capacity during the life cyle of Common shrew (after B i elak \& P u cek, 1960).

In view of all these changes it seems possible that the specific erythropoesis observed in the Common shrew and related species should be another sign of different metabolism of these animals. Investigations by De hne l (1949; 1950), K u bik (1951), P u cek (1955; 1957), C a boń (1956), B i e la k \& P u ce k (1960), have shown that the course of metabolic changes in all three representatives of the genus Sorex run along similar pathways - in the same way behaves the development of the specific erythropoesis. It is much less marked in the genus Neomys which is in agreement with similarly less marked changes in bone and organ changes in this animal. Dehnel(1950) explained these less marked changes in Neomys by a more regular and more balanced life conditions 
in which these animals live. It is possible that the $N$. fodiens which posseses poison glands and can therefore more easily provide for richer meals are less susceptible to good or bad conditions as it is the lot of the Soricidae.

The specific erythropoesis seems to be one of the means by which the Soricidae compensate the unusual metabolic conditions constituting their mode of life. The blood tissue is put under considerable stress as evidenced by the very high erythroblastic renewal, as well as the defficit of haemoglobin which has no time to acumulate in the erythroblasts. Among other factor playing a role in the heightened metabolism of the Soricidae, can be high amount of ribonucleic acid in the erythroblasts.

Whatever, however, are the reasons for such marked changes in the erythropoesis in the shrews and related species, they will remain unexplained as long as long the more detailed studies on the metabolism of Soricidae will be undertaken.

\section{SUMMARY}

A special case of erythropoesis in the genus Sorex Lin na e us, 1758 is preserted in this paper. According to our investigations the basochromatophiles and the polychromatophiles undergo a morphological change towards plasmacell-like forms. They make a considerable percentage of the erythroblasts of the blood tissue. Their characteristic morphological feature is an abundant cytoplasm, excentric nucleus and high basophilia.

Although the haemoglobin content in blood has the same values as are known for other animals (rodents and laboratory animals) the haemoglobin appears in the erythroblasts very late (as late as the late orthochromatophiles).

The number of changed erythroblasts is the greatest in the three species of Sorex it is markedly lower in Neomys and very low in Talpa.

Very young specimens of $S$. araneus and other related species do not show any noticeable differences in their erythropoesis. The specific morphological changes start to occur about the 5-6th week of their independent life and are maintained throughout the whole life cycle of the animals untill its natural death.

The meaning of this phenomenon in the biology of S. araneus and other Soricidae is discussed.

\section{REFERENCES}

1. B a z a n, I., 1952: Zmiany morfohistologiczne grasicy u Sorex araneus L. w cyklu życiowym. Ann. Univ. M. Curie-Skłodowska, C 7, 5: 253-304. Lublin.

2. Bielak, T. \& Pucek, Z., 1960: Seasonal changes in the brain-weight of the Common shrew (Sorex araneus araneus Lin n a us, 1758). Acta thericl., 3, 13: 297-300. Białowieża.

3. Borowski, S. \& Dehne 1, A., 1952: Materiały do biologii Soricidae. Ann. Univ. M. Curie-Skłodowska, C 7, 6: 305-448. Lublin.

4. B r a chet, J., 1948: Embriologie Chimique. Liege.

5. C a b o ń, K., 1956: Untersuchungen über die saisonale Veränderlichkeit des Gehirnes bei der Kleinen Spitzmaus (Sorex minutus minutus L.). Ann. Univ. M. Curie-Skłodowska, C 10, 5: 93-115. Lublin.

6. Crow croft, P., 1959: The life of the shrew. Collins, London, 
7. D e hne 1, A.: 1949: Badania nad rodzajem Sorex L. Ann. Univ. M. Curie-Skło-dowska, C 4, 17-102. Lublin.

8. D e hn e 1, A., 1950: Badania nad rodzajem Neomys $\mathrm{K}$ a u p. Ib., 5, 1: 1-64. Lu-1blin.

9. De hne 1, A., 1951: Biologia rozmnażania ryjówki Sorex araneus L. w warun-1kach laboratoryjnych. Ib., C 6, 11: 359-376. Lublin.

10. K u b i k, J., 1951: Analiza pulawskiej populacji Sorex araneus araneus L. i Sorexx minutus minutus L. Ib., 5, 11: 355-372. Lublin.

11. M a xi m o w, A., 1949: Textbook of Histology.

12. Pucek, Z., 1955: Untersuchungen über die Veränderlichkeit des Schädels imm Lebenszyklus von Sorex araneus araneus L. Ann. Univ. M. Curie-Skłodowskaa, C 9, 4: 163-211. Lublin.

13. P u c e k, Z., 1957: Histomorphologische Untersuchungen über die Winterdepres-ssion des Schädels bei Sorex L. und Neomys K a u p. Ib., C 10, 15. 399-428. Luublin.

14. [Tupikova, N. V.] Тупикова, Н. В., 1949: Питание и характер сууточной активности землероек средней полосы СССР. Зоол. Журн., 28,6: 56661 -572. Москва.

Polish Academy of Sciences, Mammals Research Institute, Białowieża, woj. Białystok.

\section{EXPLANATION OF PLATE IX.}

Fig. 1. Pseudopodia-like protrusions of the cytoplasm of an pronormoblast.

Fig. 2-3. Changed erytroblasts, Sorex araneus.

Fig. 4. Sicista betulina polychromatophile - example of a transitory cell - the lighht cell in the centre of the photograph.

\section{STRESZCZENIE}

W niniejszej pracy przedstawiono szczególny przypadek swoistej erytropoezy u ræodzaju Sorex L in n a e us, 1758. W badaniach naszych stwierdzono, że bazochromatctofile i polichromatofile ulegają zmianom morfologicznym w kierunku form plasmanacyto-podobnych. Stanowią one znaczny odsetek erytroblastów tkanki krwictwórczezej i ich cechą charakterystyczną jest obfita cytoplasma, ekscentryczne jądro i silna babazofilia (Ryc. 1-4).

Jakkolwiek zawartość hemoglobiny we krwi obwodowej nie jest niższa niż u innycych rodzajów zwierząt, pojawia się ona w erytroblastach bardzo późno i wysyca dopierero bardzo późne ortochromatofile (Tabela 1).

Ilość pojawiających się zmienionych erytroblastów jest największa u trzech ba:alanych rodzajów Sorex, wyraźnie niższa u Neomys i bardzo niska u Talpa (Tabela 2 2).

$\mathrm{U}$ bardzo młodych osobników $S$, araneus i innych pokrewnych gatunków nie ulubserwuje się wyraźnych zmian erytropoezy z wyjątkiem bardzo silnej jej odnıwwy. Swoiste zmiany natomiast zaczynają się w 5-6 tygodniu samodzielnego życia z:wivierzęcia i utrzymują się w ciągu całego cyklu życiowego ryjówek aż do ich naturaininej śmierci (Ryc. 5).

Znaczenie tego zjawiska w biologii ryjówki jest omạwianę w dyskusji, 


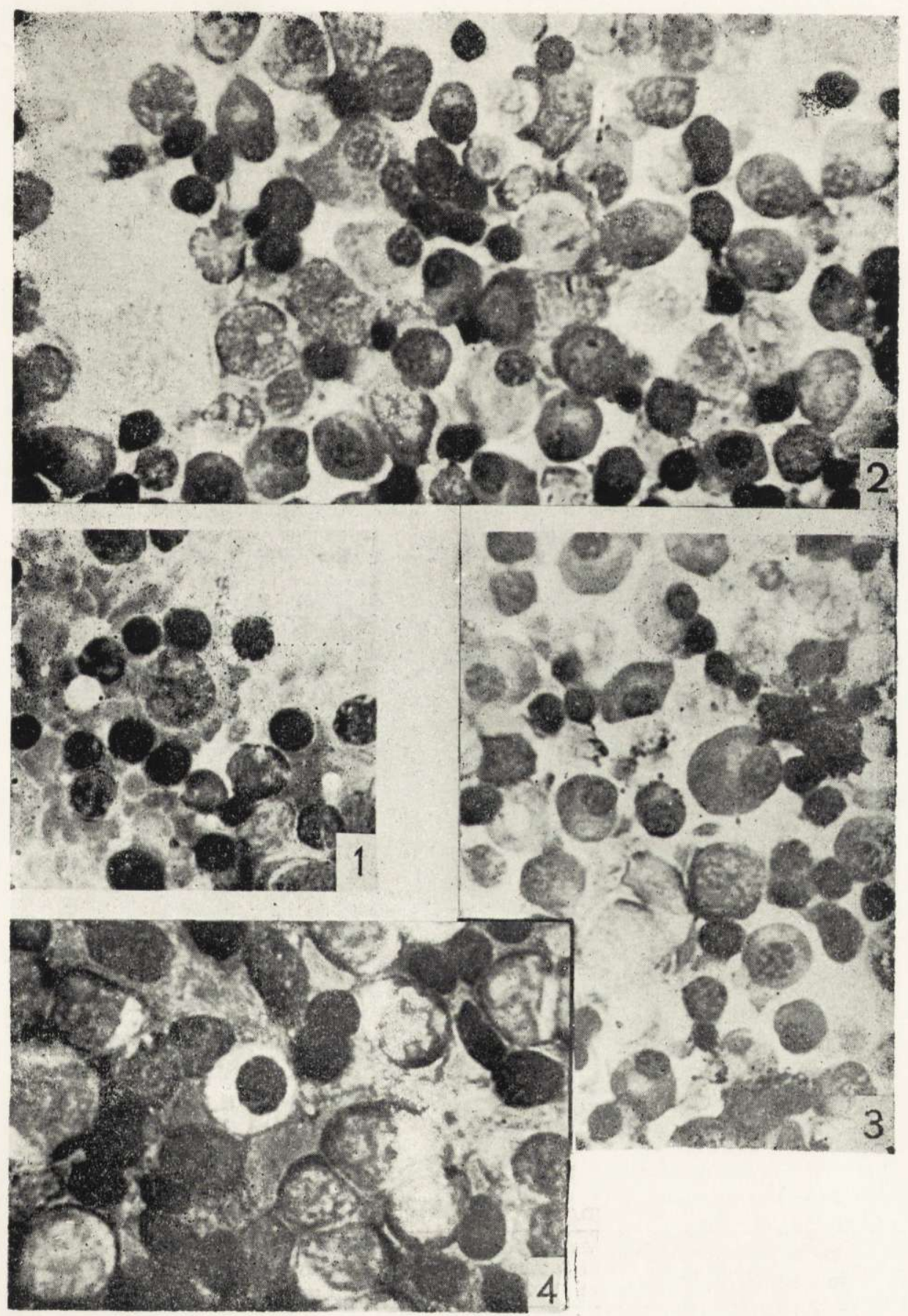

E. Perkowska

Z. Fисек phot. 
BIBLIOTEKA

Instytutu Biologii Ssaków

Polskiej Akademii Nauk

$\mathrm{NrCz} .40 .2$

PANSTWOWE WYDAWNICTWO NAUKOWE * WARSZAWA 1963

Nakiad 1400 ejz. Ark. wyd. 1. Maszynopis otrzymano 25.IV.1963. Podpisano do druku 31.VIII.1963. Druk ukończono 15.IX.1963. Papier druk. sat. k1. III 80 g. Format B5. Cena $5 \mathrm{zl}$.

Białostockie Zakłady Graficzne. Zam. $1639 *$ A-3. 